Doi: https://doi.org/10.31578/jebs.v6i1.220

\title{
Hazard Perception and Disaster Information of Turkish Secondary School Students*
}

\author{
İlyas Kara** \\ Nevin Özdemir ${ }^{* * *}$
}

\begin{abstract}
The purpose of this paper is to examine the relationship between the levels of hazard awareness, risk perceptions, the knowledge of response-related protective behavior, and disaster knowledge within the framework of secondary school curriculum in Turkey. A questionnaire examining various measures including hazard awareness, risk perceptions, and general disaster knowledge test was answered by 8th-grade students of schools in Erbaa, Niksar, and Taşova located in North Anatolian Fault Zone (NAFZ) in Turkey. The data from a total of 654 surveys were analyzed utilizing chi-squared, $t$-test, and ANOVA.The research findings proved that students' disaster awareness and risk perceptions about the environment in which they live are quite realistic. The high levels of earthquake risk perception and fear were related to the fact that they live in settlements located in NAFZ with the highest level of earthquake risk in Turkey. However, research findings proved that most of the students had a fairly low level of knowledge of response-related protective behaviors, and significant differences were found in the context of schools and settlements.
\end{abstract}

Key words: 8th-grade students, risk assessment, hazard education, disaster education, Turkey

\section{Introduction}

As stated by the United Nations Office for Disaster Risk Reduction (UNDRR), a disaster can be defined as "a serious disruption of the functioning of a community or society involving widespread human, material, economic or environmental losses and impacts, which exceeds the ability of the affected community or society to cope with using its resources" (United Nations General Assembly, 2016, p.13). A disaster is a result of the combination of hazard, vulnerability, and insufficient capacity or measures to reduce the potential chances of risk. A disaster happens when a hazard impacts the vulnerable population and causes damage, casualties, and disruption (Khan \& Khan, 2008). In this context, Turkey is one of the countries most damaged by disasters. The areas with high earthquake risk are approximately $93 \%$ of the total area of the country; consequently, $98 \%$ of the country's population and 98\% of the industrial facilities are located in these areas with high earthquake risk (TMMOB Makina Mühendisleri Odası, 2012). Besides, natural events such as floods, strong winds, landslides, rockfalls, and avalanches occur frequently due to the tectonic, climatic, and topographic characteristics of the country. These hazardous natural events can sometimes turn into disasters with huge losses of life and property. Furthermore, in Turkey, it has been observed that human-caused events such as fires, traffic crashes, terrorist incidents, etc. have turned into disasters many times. Therefore, similarly to many countries with high disaster risk, issues such as disaster management, emergency management, disaster risk management have always been important for Turkey.

\footnotetext{
*The data used in this article were obtained from the postgraduate thesis of the first author.

*** Educational consultor of the Turkish Ministry of Education in Strasbourg, France.

*** Assoc. Prof., Education Faculty, Ondokuz Mayıs University, Samsun, Turkey

Corresponding Email: nevino@omu.edu.tr ; nvnozdmr@hotmail.com
} 
As stated in the UNIDRR glossary, disaster management includes actions related to organization, planning, and application of measures preparing for, responding to, and recovering from disasters. Disaster risk management is the application of disaster risk reduction policies and strategies to prevent new disaster risk, reduce existing disaster risk and manage residual risk, contributing to the strengthening of resilience and reduction of disaster losses (Unıted Natıons Offıce for Dısaster Rısk Reductıon (UNDRR, 2017). Two major earthquakes called Düzce and Gölcük in 1999 became a turning point for Turkey's disaster risk management strategy. Following these earthquakes, which caused many losses of life and property in Kocaeli ve Düzce provinces, some attempts were carried out to implement the integrated disaster management system focused on disaster risk management; and to accomplish this, the Presidency Disaster and Emergency Management Centre known as AFAD was established in 2009 (AFAD, 2016). This was a very radical step in the transition from emergency management ${ }^{1}$ to disaster risk management (Şengün, 2018).

The previous studies on disaster education have pointed to the importance of disaster education in creating a safe society through developing disaster management skills and raising awareness on disasters (Dufty, 2011; Nielsen \& Lidstone, 1998). It was also emphasized that schools had a significant positive role in disaster risk reduction (DRR) education concerning disaster safety and preparation education for students and their families (Shaw \& Kobayashi, 2001; Shiwaku \& Fernandez, 2011). Moreover, many studies on DRR specify that disaster education at schools should be arranged appropriately and sustainably for all age levels (Shaw, Takeuchi, \& Shiwaku, 2011). Smyth (1996) suggested that the training campaigns and programs initiated for improving the information, skills, and behaviors necessary to solve environmental issues should be arranged sustainably according to target groups. Some studies demonstrate that effective training provided to students also helps to increase the DRR awareness of their families (Johnson, Ronan, Johnston, \& Peace, 2016; Lidstone, Stoltman, \& DeChano, 2004; Ronan et al., 2015; Ronan et al., 2008).

In line with this, Hyogo Framework for Action (HFA), supported by the United Nations Office for Disaster Risk Reduction (UN/ISDR) and United Nations International Children's Emergency Fund (UNICEF\&UNISDR), clearly stated that the two most substantial components of disaster risk management and sustainable development are knowledge and training (AFAD, 2015). In this context, various campaigns were launched to raise global awareness on disasters by the United Nations' International Strategy for Disaster Reduction (ISDR) secretariat tasked with supporting governments in the implementation of HFA (UN/ISDR, 2007). These global policies under the coordination of the United Nations started with 10 years of Disaster Mitigation (1990-1999), continued with the Millennium Development Plan - MDGs (2000-2015) and Hyogo Action Plan (2005-2015), and finally, the Sendai Framework was declared (Raju \& da Costa, 2018; UNISDR, 2015). In the 2006-2007 period, the global disaster risk reduction (DRR) action, started with the title "Disaster Risk Reduction Begins at School," was very informative about how to support and develop local and national initiatives to reduce disaster risk through education, as well as general information on disaster education and disaster risk reduction activities (UN/ISDR, 2006). Later, some decisions were taken, regarding the adaptation of DRR to the curricula of schools by 2015 (UNICEF \& UNISDR, 2011). Finally, between 2015 and 2030, member countries of the United Nations (UN) around the world will conduct a variety of efforts within the context of the four Priority Areas contained in the Sendai Framework. The four priority areas are listed as understanding disaster risk, strengthening disaster risk governance to manage disaster risk, investing in disaster risk reduction for resilience, and enhancing disaster preparedness for effective response and to "build back better" in recovery, rehabilitation, and reconstruction, respectively (United Nations, 2015).

In Turkey, which is one of the member-countries of the UN, some practices on disaster risk management were implemented following the above developments. The European Natural Disasters Education Centre, which is a special center within the EUR-OPA Major Hazards Agreement ${ }^{\mathrm{ti}}$, was the establishment under the Education Coordination Branch of AFAD (AFAD, 2015). Furthermore, Turkey's Ministry of National Education has decided to restructure the curriculum at every level of formal 
education, and this new curriculum prepared within the framework of the constructivist approach was put into practice in all primary and secondary education institutions in 2005. Besides, some regulations were made to adapt disaster education to this new curriculum. The curriculum of primary education, implemented from 2005 to 2018, was prepared within the framework of an intermediate approachiii. The "disaster education and safe living" were among these intermediate domains by associating with the units of the courses such as Knowledge of Life, Social Studies, Science and Technology, Math and Turkish at primary (1st, 2nd, 3 rd, 4th grades), and secondary (5th, 6th, 7th, 8th grades) levels (Öcal, 2010).

However, there was some criticism about the disaster topics in this new curriculum. For example; Öcal, Çakır and Özelmacı (2016), and Kırıkkaya, Ünver and Çakın (2011) reported that the majority of the subjects on disasters were part of the content of Science and Technology course, while the content of other courses included only subjects related to earthquakes. Furthermore, the content of the units related to disasters at primary and secondary levels (age 6-14) generally consisted of preparation and protection against disasters, while the disaster content of those at high-school level (age 15-17) was related to detailed information about the causes of disasters, civil protection, mitigation and response activities (UNICEF \& UNISDR, 2011). On the other hand, it appears that the majority of the previous studies on disasters and disaster education in Turkey focused on earthquakes (for example, Aydin \& Coskun, 2010; Gulay, 2010; Kirikkaya, Çakin, Imali, \& Bozkurt, 2011; Öcal \& Topkaya, 2011; Oral, Yenel, Oral, Aydin, \& Tuncay, 2013). The literature review of Değirmençay and Cin (2016) reported that the majority of these studies were quantitative studies focused on keywords or titles such as disaster protective behavior, disaster knowledge, hazard perception, metaphoric studies on disasters, methods used in teaching disaster subjects, disaster curriculum, and emergency management. Besides, some studies were focused on topics such as the concept of disaster (Dikmenli \& Gafa, 2017; Taşcı \& Ünver, 2017), disaster awareness (Pinar, 2017), disaster education in schools or curricula (Kırıkkaya, Ünver, \& Çakın, 2011; Öcal, 2010; Özmen \& İnce, 2017; Yılmaz, 2014), disaster information and hazard awareness of teachers or prospective teachers (Cin, 2010; Dikmenli \& Yakar, 2019; Sözcü \& Aydınözü, 2019). In a study describing teachers' judgments on the objectives of disaster education integrated into primary and middle school curricula in Turkey (Erdur-Baker, Kasapoğlu, \& Yılmaz, 2015), it was reported that the teachers who participated in the study did not perceive these objectives as clear, measurable and attainable.

Only a limited number of studies focused on topics such as the impact on students' disaster awareness or the effectiveness of disaster education in the formal education curriculum of Turkey (for example, Akçil, Toğrol, Mercan, \& Tanırcan, 2014; Fetihi \& Gülay, 2011; Özgüven, 2006). In such a study, Öcal et al. (2016) claimed that disaster content in primary and secondary education curricula introduced in 2005 included most basic information such as the classification of cases and terms, whereas this content was rather inadequate in terms of applications that would encourage students to practice and solve problems. Although this curriculum was developed based upon constructivist approach, research studies showed that most teachers tended to use traditional teaching methods and textbooks as teaching materials for disaster education, since they do not have sufficient knowledge, skills or willingness to apply other alternative teaching methods (Öcal, 2005).

It has been claimed in some previous studies that examine the impact of disasters on children's psychology that reconciling hazard education in schools and hazard education in families or homes has a significant potential for both the physical and emotional preparedness of children (Ronan, Alisic, Towers, Johnson, \& Johnston, 2015; Ronan, Crellin, \& Johnston, 2010; Ronan et al., 2008; Ronan \& Johnston, 2001a). However, there are a limited number of studies that have investigated the impacts of disasters on child psychology in Turkey (for example, Danışman and Okay, 2017; Erkan, 2010). Of course, without a disaster experience, it is difficult to judge whether or not the hazard training provided to students is effective. Besides, the effectiveness of a hazard education program can be assessed by measuring the difference between the participants and non-participants of 
hazard training (Finnis, Johnston, Ronan, \& White, 2010). In this context, there was not enough evidence in the literature about whether the disaster education carried out through formal education or various campaigns was effective.

To investigate the effectiveness of disaster education content in the formal educational curriculum in Turkey, this study focused on the knowledge of disaster and response-related protective behaviors, risk perceptions, and hazard awareness of 8thgrade students. Based on some previous studies that investigated the students' risk perceptions, hazard awareness and preparations (Finnis et al., 2010; K. Finnis, Standring, Johnston, \& Ronan, 2004; Johnson, Ronan, Johnston, \& Peace, 2016; Ronan \& Johnston, 2001a), this study was conducted with 8th-grade students in Erbaa, Niksar and Taşova districts in the eastern part of North Anatolian Fault Zone (NAFZ). Erbaa and Niksar are within the administrative boundaries of Tokat province, and Taşova is within the administrative borders of Amasya province. These three sites are ranked on the east-west direction in the tectonic depression line where Kelkit River flows, which is one of Yeşilırmak's tributaries (Figure 1).

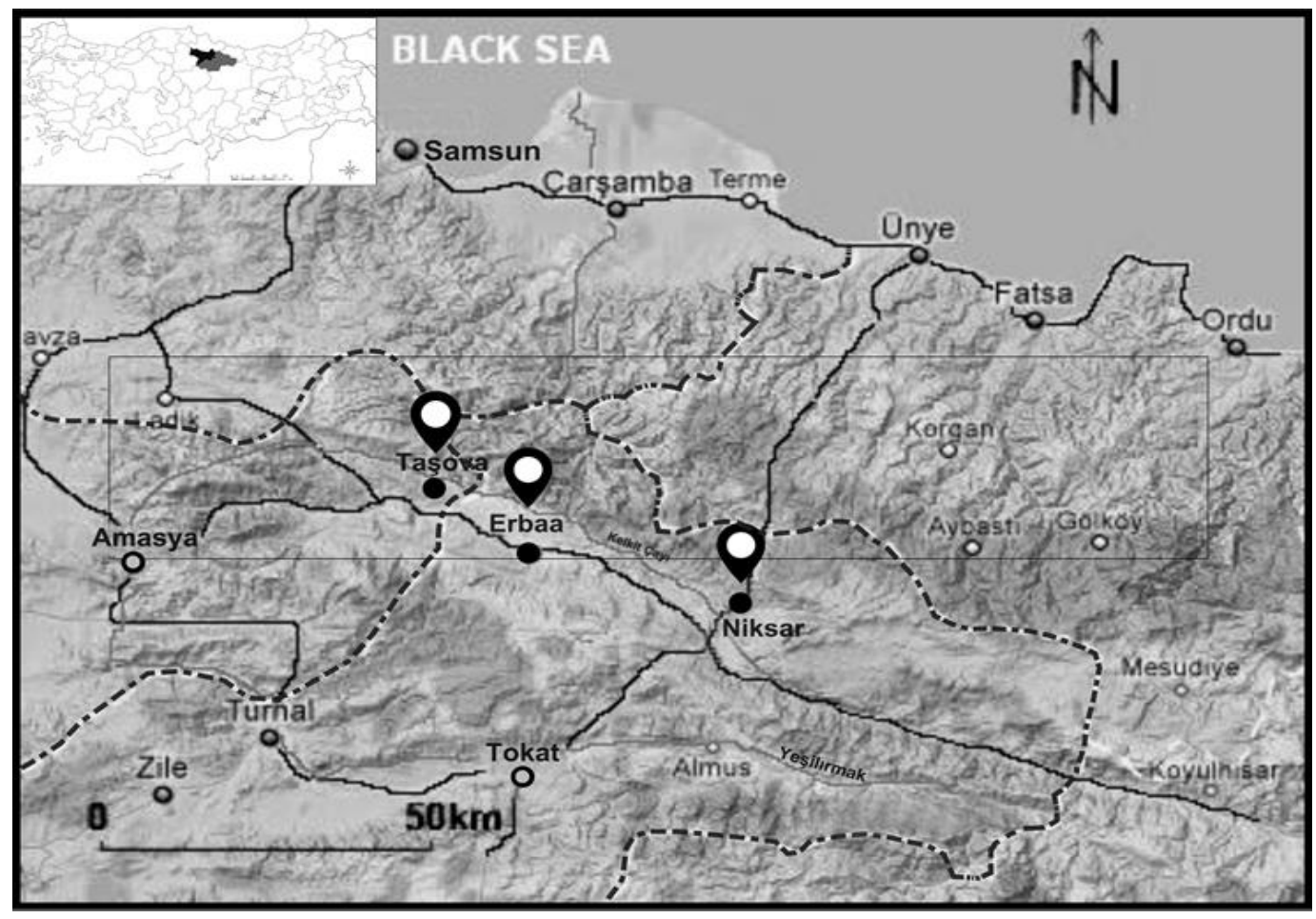

Figüre 1. The locations of settlements where the study was carried out

In the past, destructive earthquakes occurred on this line, such as Osmancık earthquakes in $1910(\mathrm{Mw}=6.1)$ and 1942 $(M w=5.9)$, Niksar-Erbaa earthquake in 1942 (Mw=7.1), and Lâdik-Tosya earthquake in 1943 (Mw=7.3) (Akin, Topal, \& Kramer, 2013; Barka, Akyüz, Cohen, \& Watchorn, 2000; Bohnhoff, Martínez-Garzón, Bulut, Stierle, \& Ben-Zion, 2016). Besides, landslides (Bilgehan, 2004), floods, strong winds (Çelik et al., 2018), and fire disasters were observed in this region. However, disaster, hazard, and risk awareness of students living in an area with a high risk of disasters was limited by the course content in their schools.

In this study, disaster knowledge, disaster and hazard awareness, risk perception, risk reduction, reaction behaviors, and emotion-focused coping factors of the students were examined in the context of some variables. The research findings are related to the following problems:

1. Are the students aware of the hazards in their habitat; and what perception of risk do they have? 
2. What degree of awareness of emotion-focused coping factors do the students possess about the overall fear levels such as perceived parental fear levels, perceived emotional coping ability, and anxiety for each of the 9 hazards listed?

3. What knowledge of harm mitigation and response behavior on problem-oriented coping for readiness to disasters do they have?

4. What is the general disaster knowledge level of the students according to the findings of the disaster knowledge test (DKT) prepared based on the disaster content in the primary and secondary education curriculum?

\section{Methodology}

\subsection{Procedure}

In Turkey, the duration of compulsory education is currently 12 years, including 4 years of primary school, 4 years of secondary school, and 4 years of high school. The reason why the study sample consisted of $8^{\text {th }}$-grade students was to find out what impact of the disaster content in the curriculum before the high school level had on the emotional and cognitive development of children. In the 2015-2016 academic year, in which this study was conducted, a total of 3020 students were studying in the $8^{\text {th }}$ grade of 64 secondary schools in Niksar, Erbaa, and Taşova districts. The schools in the study sample were determined to take into account the socio-economic profiles of students in schools with the help of local education authorities. A total of 654 students from 7 schools in Erbaa ( $n=255), 6$ schools in Niksar $(n=197)$, and 5 schools in Taşova $(n=202)$ participated in the study. The participants consisted of $324(49.5 \%)$ female and 330 (50.5\%) male students. The questionnaire used as a data collection tool was distributed to students under the guidance of the first author and teachers in these schools.

\subsection{Measures}

A questionnaire consisting of two parts was used as a data collection tool in the study. The items in the first part of this questionnaire were prepared based on the hazard education survey (HES) used in Ronan and Johnston (2003). Firstly, permission was obtained by contacting the responsible author to use this scale in our study. Then, a pilot study was conducted for providing the validity and reliability of the Turkish version of the tool. The original form of the HES included both self-report indices and a home-based instrument filled out by parents. However, in this study, a questionnaire was not sent to the families. In the original scale, there were items on hazard awareness, risk perceptions, knowledge of response-related protective behaviors, and preparedness activities (such as having family plans, practicing in-home and school-based emergency activities, and having adopted specific household hazard adjustments).

Furthermore, in the original HES, there was a hazard list to assess students' hazard awareness and risk perceptions, and this list consisted of those cases accepted as hazards for those students's habitat who participated in the study (Ronan \& Johnston, 2001b; 2003). Similarly, the hazard list in the Turkish version of HES was created considering the potential hazards and risks in the location where our study was carried out. When the disaster events that occurred in the study location in the past were examined, it was understood that tsunami and volcanic eruption, which are in the hazard list of original HES, are not among the hazards that threaten the study location. However, tsunami and volcanic eruptions were also listed among hazards on the Turkish HES to test whether students had misunderstandings about hazards in their habitat.

The readiness items of the original scale consisted of three parts: knowledge of response-related protective behaviors, family plans, home and school-based practice, and hazard adjustments (Ronan \& Johnston, 2001b, p. 1058). Since there is no content related to protective behaviors for both tsunami and volcanic eruptions in the content of the courses up to the 8th grade, 
it was decided not to include the protective behavior items related to these hazards in the Turkish HES ${ }^{\text {iv }}$. Instead, 6 hazards (earthquake, fire, flood/overflow, landslide, storm with high winds and avalanche) were identified by examining the data of AFAD on disasters in the past years at the study location; considering the studies of Ronan and Johnston (2001, 2003), online resources, and brochures prepared by AFAD and primary and secondary school curricula, these hazards-related protective behavior items were prepared. Readiness items about family plans and home- and school-based practice, and hazard adjustments in the original HES were included in the tool prepared for the pilot study. However, the results of this study showed that among the total of 200 students there was none who had such readiness at their homes or schools. Therefore, these readiness items were not used in our study and the tool was significantly modified.

The Turkish HES modified for this study consists of the following sections:

The hazard awareness and risk perception: hazards were listed in the questionnaire form (flood, earthquake, house fire, storm with high winds, landslide, avalanche, volcanic eruption, chemical spill, tsunami) and the students were asked to mark the two most likely to affect them at home in order of importance $\left(1^{\text {st }}\right.$ degree, $2^{\text {nd }}$ degree $)$. Besides, a 3 -point scale $(1=$ likely, $2=$ there is a chance, 3 = unlikely) was used to measure how the students rated the likelihood of the occurrence of each hazard in their area and their potential to cause damage. The Cronbach alpha ( $\alpha$ ) values of 9 risk perception items for the settlement were found to be between 0.76 and 0.82 .

Emotion-focused coping factors: in this section, the students were asked 12 questions prepared in a three-point Likert type: 1. "Do you feel sadness and fear when you hear about disaster or think about it?" (1= often, 2= sometimes, $3=$ not at all). 2 . "Do you think that the members of your family feel upset when a disaster is talked about?" $(1=$ yes, $2=$ not sure, $3=$ no). 3 . If you experience a disaster hazard, can you cope with the negative psychological effects (fear, sadness, depression, etc.) arising due to the disaster? $(1=$ completely able, $2=$ not sure, $3=$ not at all able). 4 . The expressions 4 to 12 in this section refer to the 9 types of hazards listed above, and the students were asked:

When you talk about these disasters or when you think about these, do you feel sadness and fear? $(1=y e s, 2=$ not sure, 3 $=$ no). It was determined that the Cronbach Alpha $(\alpha)$ value of 12 items in this section varied between 0.66 and 0.72 .

Readiness (Problem-oriented coping): knowledge of harm mitigation and response behavior. These items included disaster occurrence activities to be carried out in the event of a disaster. For each hazard (earthquake, fire, flood/overflow, landslide, storm with high winds and avalanche), students were asked to endorse the item or items they felt were appropriate responses in the event of that hazard (e.g. "Duck, cover, hold" in the event of an earthquake). Each hazard had a range of four to six possible responses with differing numbers of correct responses per hazard. There were 13 correct protective behavior items in total, and eight of these items refer to the protective behaviors that are vital to do in case of a hazard. Students were instructed that they could mark more than one option if it represented an appropriate response to that hazard. The alpha reliability of these items was found as 0.83 .

The disaster knowledge test: There was a multiple-choice disaster knowledge test (DKT) consisting of 23 questions. These questions were developed by researchers to measure the level of students' knowledge about disasters by taking into account the content related to disasters in the curriculum until the 8th grade. These questions consisted of questions measuring students' level of knowledge such as the causes and distribution of disasters (for example; which of the following cannot be said to be effective in the occurrence of landslides in the Black Sea Region and in which of the disasters given below the weather conditions of the region do not affect?). In the DKT preparation process, firstly, a pool of questions was created by examining the content of the courses in the curriculum from the first to the eighth grade. Subsequently, 50 items from this question pool were selected 
for the pilot study considering expert opinions. A pilot study was conducted with the participation of $2508^{\text {th }}$-grade students. Considering the analysis of the data obtained from the pilot study, 27 questions were excluded from the test as the item difficulty index $(p)$ was between 0.40 and 0.80 , and the discrimination index $(d)$ was less than 0.30 . The discriminant index of the remaining 23 substances ranged from 0.56 and 0.30 and the item difficulty index of them from 0.40 to 0.79 , and the Cronbach alpha $(\alpha)$ reliability of total DKT was found to be 0.75 .

\section{Results of Data Analyses}

\subsection{Hazard awareness and risk perceptions}

As seen in table 1, the earthquake was chosen by $81 \%$ of 654 students as the most likely hazard to occur at home, while the home fire was chosen by more than half (54\%) of students as the second possible hazard. Storms with high winds, earthquakes, landslides, and floods, respectively, were selected as potential secondary hazards by $39 \%$ of students, whereas only $6 \%$ of the students chose chemical spill, tsunami, volcanic eruption, avalanche as a possible secondary hazard at home. No significant differences were found between the groups of the hazards chosen as the most likely to occur at home based on gender, district, and school variables. Earthquake, fire, flood, storms with high winds, and landslide respectively were chosen as likely to occur and cause injury locally in the future. However, tsunami and volcano eruption which are not possible to occur locally were chosen as likely. As a result of independent sample t-test analysis for gender, a significant difference was found only for floods among the 9 hazards in the list of the likelihood of occurring locally soon, $t_{(643)}<1$ and $p>0.05$.

Table I. The frequencies of the most possible (second most possible) disasters at home and chi-square analyses according to gender, district and school variables

\begin{tabular}{|c|c|c|c|c|c|c|}
\hline Hazards & $\begin{array}{c}\text { Hazard } \\
\text { awareness (\%) }\end{array}$ & & Value & $x^{2}$ & Df & $P^{*}$ \\
\hline Earthquake & $81(11)$ & 1.Hazard & Gender & 9.28 & 7 & .16 \\
\hline Flood & $8(8)$ & & District & 20.83 & 14 & .63 \\
\hline Fire & $8(54)$ & & School & 196.57 & 119 & .85 \\
\hline Storm with highwinds & $2(15)$ & 2.Hazard & Gender & 6.17 & 8 & .24 \\
\hline Volcanic eruption & $0.8(0.8)$ & & District & 58.51 & 16 & $.04^{*}$ \\
\hline Landslide & $0.3(5.8)$ & & School & 326.64 & 136 & $.04^{*}$ \\
\hline Tsunami & $0.3(1.7)$ & & & & & \\
\hline Avalanche & $0.3(0.6)$ & & & & & \\
\hline Chemical spill & $0(1.8)$ & & & & & \\
\hline \multicolumn{7}{|l|}{$* p \leq 0.05$} \\
\hline
\end{tabular}

Table II. Descriptive statistics of hazards most likely to occur locally in the future, ANOVA and t-test results

\begin{tabular}{lcccccccccc}
\hline \multicolumn{2}{c}{$\begin{array}{c}\text { Risk perception-Future likelihood of } \\
\text { occurrence }\end{array}$} & & & \multicolumn{3}{c}{ ANOVA } & \multicolumn{2}{c}{ Schools } & \multicolumn{3}{c}{ Settlements } & Independent samples \\
test for gender
\end{tabular}




$\begin{array}{lccccccc}\text { Fire } & 1.19 & 0.45 & 1.72 & 0.04^{*} & 2.85 & 0.06 & t_{(652)}<1 \\ \text { Storm with high winds } & 1.58 & 0.68 & 1.23 & 1.99 & 2.65 & 0.07 & t_{(651)}<1 \\ \text { Volcanic eruption } & 2.18 & 0.90 & 6.77 & 0.00^{*} & 17.88 & 0.00^{*} & t_{(652)}<1 \\ \text { Landslide } & 1.73 & 0.77 & 2.98 & 0.00^{*} & 18.16 & 0.00^{*} & t_{(652)}<1 \\ \text { Tsunami } & 2.13 & 0.88 & 7.21 & 0.00^{*} & 26.06 & 0.00^{*} & t_{(652)}<1 \\ \text { Avalanche } & 1.91 & 0.83 & 3.98 & 0.00^{*} & 17.36 & 0.00^{*} & t_{(652)}<1 \\ \text { Chemical spill } & 2.00 & .84 & 4.07 & 0.00^{*} & 9.82 & 0.00^{*} & t_{(651)<1} \\ { }^{*} p \leq 0.00 & & & & & & & \end{array}$

\subsection{Emotion-focused coping factors}

In terms of overall fear levels, perceived parental fear levels, perceived emotional coping ability, and anxiety for each of the 9 hazards listed, as shown in Table III, the mean of the total 12 items was found as 1.5; and the means of these items varied between 1.22 (earthquake-related fear) and 1.79 (chemical spill-related fear). Also, the means of each emotion-focused item showed that female students 'anxiety and fear levels $(n=324, \bar{X}=1.27)$ were higher than those of male students $(n=330, \bar{X}=1,60)$. The results of the independent samples t-test for gender indicated that there were significant differences in all emotion-oriented items except storm with high winds and tsunami fears. The ANOVA analysis determined that there was a significant difference between some schools in all emotion-focused items except for perceptions of parental distress. Also, significant differences were found between settlements in all emotion-focused items except perceived emotional coping, sadness, or fear related to earthquake, flood, and fire items. The fear and anxiety levels of the Taşova sample were higher than the anxiety levels of the Erbaa and Niksar samples.

Table III. Emotion-Focused Factors: Descriptive statistics, ANOVA and T-test results

\begin{tabular}{|c|c|c|c|c|c|c|c|c|c|}
\hline \multirow{3}{*}{$\begin{array}{l}\text { Emotion-focused coping factors } \\
\text { Emotion-Focused Factors }\end{array}$} & \multirow[b]{3}{*}{$\bar{X}$} & \multirow[b]{3}{*}{ sd } & \multicolumn{6}{|c|}{ ANOVA } & \multirow{3}{*}{$\begin{array}{l}\text { Independent } \\
\text { samples test } \\
\text { for gender }\end{array}$} \\
\hline & & & \multicolumn{3}{|c|}{ Between Schools } & \multicolumn{3}{|c|}{ Between Settlements } & \\
\hline & & & df & $F$ & $p$ & $\mathrm{df}$ & $F$ & $P$ & \\
\hline Hazard-Related Fears & 1.44 & .73 & \multirow{8}{*}{$\begin{array}{c}17 \\
636\end{array}$} & 2.12 & $.00^{*}$ & \multirow{8}{*}{$\begin{array}{c}2 \\
651\end{array}$} & 7.14 & $.00^{*}$ & $t_{(611)}<1^{*}$ \\
\hline Perceptions of Parental Distress & 1.72 & .77 & & 1.31 & .18 & & 6.12 & $.00^{*}$ & $t_{(650)}<1^{*}$ \\
\hline Perceived Emotional Coping & 1.61 & .68 & & 1.70 & $.03^{\star *}$ & & 1.71 & .18 & $t_{(651)}<1^{\star}$ \\
\hline Earthquake & 1.22 & .55 & & 1.72 & $.03^{\star *}$ & & 1.36 & .32 & $t_{(630)}<1^{\star}$ \\
\hline Flood & 1.70 & .85 & & 2.77 & $.00^{\star}$ & & 1.59 & .20 & $t_{(554)}<1^{\star}$ \\
\hline Fire & 1.33 & .64 & & 1.66 & $.04^{\star *}$ & & 0.18 & .84 & $t_{(604)}<1^{*}$ \\
\hline Storm with high winds & 1.76 & .77 & & 1.90 & $.01^{\star}$ & & 5.84 & $.00 *$ & $t_{(648)}<1^{*}$ \\
\hline Volcanic eruption & 1.75 & .85 & & 4.03 & $.00^{*}$ & & 6.58 & $.00^{*}$ & $t_{(635)}<1^{*}$ \\
\hline Landslide & 1.71 & .78 & & 3.38 & $.00^{*}$ & & 11.65 & $.00^{*}$ & $t_{(645)}<1^{*}$ \\
\hline Tsunami & 1.77 & .84 & & 3.82 & $.00^{*}$ & & 13.17 & $.00^{\star}$ & $t_{(649)}<1^{*}$ \\
\hline Avalanche & 1.73 & .81 & & 3.09 & $.00^{*}$ & & 5.63 & $.00^{*}$ & $t_{(648)}<1^{*}$ \\
\hline Chemical spill & 1.79 & .83 & & 2.79 & $.00^{*}$ & & 4.27 & $.01^{*}$ & $t_{(649)}<1^{*}$ \\
\hline Total & 1.52 & .43 & & 3.44 & $.00^{*}$ & & 10.86 & $.00^{*}$ & $t_{(624)}<1^{*}$ \\
\hline
\end{tabular}

${ }^{\star} p \leq 0.01$

\subsection{Problem-oriented coping: knowledge of harm mitigation and response behavior}

There were no students who answered all 13 correct behavior items in this section of the questionnaire assessing the knowledge the students possessed concerning the disaster and the best action to take in the event of a disaster. There was a possibility of eight vitally correct responses, and among 654 students, only 8 were able to correctly mark all the vital behaviors, while 39 students could not mark any correct behavior. Regarding the means of vital and total safe behaviors $(N=654, \bar{X}=5.1)$, the students were able to correctly respond to only half of the harm mitigation and response behavior items (table IV). There was no significant 
difference between female and male students concerning the knowledge of total and vital safe behaviors. However, the ANOVA results suggested significant differences in the comparison of schools and settlements. Among the 18 schools in the sample, Niksar Secondary School had the lowest average in total and vital safe behaviors $\left(n=43, \bar{X}_{t}=3.14, \bar{X}_{v}=2.86\right)$ while the Çakır Secondary School had the highest average $\left(n=16, \bar{X}_{t}=6.63, \bar{X}_{v}=5.44\right)$. The total and vital safe behavior information averages were ranked as Niksar $\left(n=197, \bar{X}_{\mathrm{t}}=4.69, \bar{X}_{\mathrm{v}}=4.19\right)$, Taşova $\left(\mathrm{n}=202, \bar{X}_{\mathrm{t}}=5.20, \bar{X}_{\mathrm{v}}=4.50\right)$ ve Erbaa $\left(\mathrm{n}=255, \bar{X}_{\mathrm{t}}=5.34, \bar{X}_{\mathrm{v}}=4.62\right)$. The significant difference was between Erbaa and Niksar students.

Table IV: Descriptive statistics for knowledge of problem-focused coping behaviours and ANOVA, t-test results

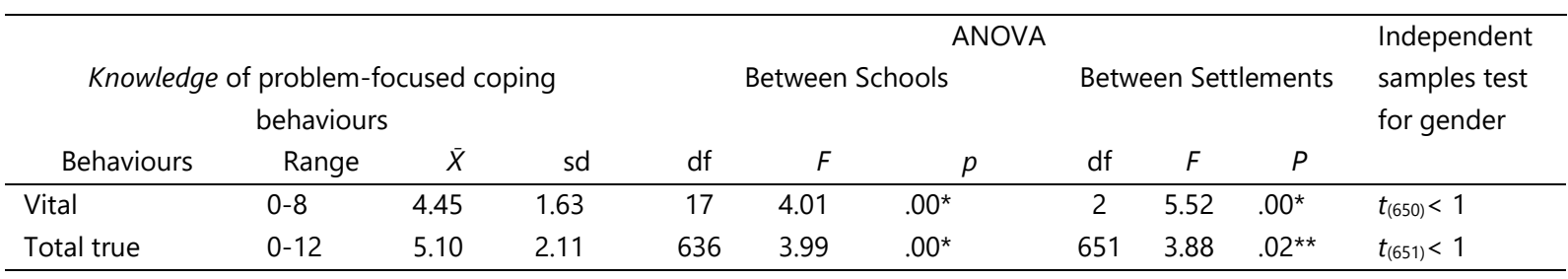

${ }^{*} p \leq 0.01 ;{ }^{* *} p \leq 0.05$

\subsection{The results disaster knowledge test (DKT):}

Table $V$ infers that the average of DKT scores was 12.18 and that these scores showed a significant difference according to gender, school, and settlement variables. The scores of the female students $(n=324, \bar{X}=12.61)$ were above the mean and higher than those of the male students $(n=330, \bar{X}=11.77)$. The mean of the DKT scores of the schools $(n=18)$ varied between 9.38 and 15.22 , and half of the schools fell below the mean. The highest score belonged to the Erbaa schools $(n=7, \bar{X}=12.64)$, they were followed by Taşova $(n=5, \bar{X}=12.27)$ and Niksar $(n=6, \bar{X}=11.49)$ schools, respectively. Scheffe analysis results of the Post Hoc test indicates that the significant difference was between the Niksar and Erbaa schools.

Table V. Descriptive statistics for disaster knowledge test and ANOVA, t-test results

\begin{tabular}{|c|c|c|c|c|c|c|c|c|c|c|}
\hline & & & & \multicolumn{6}{|c|}{ ANOVA } & Independent \\
\hline \multicolumn{4}{|c|}{ Disaster knowledge test } & \multicolumn{3}{|c|}{ Between Schools } & \multicolumn{3}{|c|}{ Between Settlements } & samples test \\
\hline Test scores & Range & $\bar{x}$ & sd & df & $F$ & $p$ & $\mathrm{df}$ & $F$ & $P$ & for gender \\
\hline \multirow[t]{2}{*}{ Total } & $0-22$ & $12 . .55$ & 4.37 & 17 & 4.63 & $.00^{\star}$ & 2 & 4.23 & $.02^{\star \star}$ & $t_{(652)}<1^{\star *}$ \\
\hline & & & & 636 & & & 651 & & & \\
\hline
\end{tabular}

${ }^{\star} p \leq 0.01 ;{ }^{* *} p \leq 0.05$

\section{Discussion}

According to the research findings, the students' awareness and risk perceptions about the potential hazards to occur at home and injury are quite realistic. In previous years, disasters caused by natural causes such as earthquakes, floods, landslides, storms with high winds, and avalanches, and fires caused by people occurred at the research site. This event also sometimes caused deaths and property losses. For example; almost all the villages between Niksar and Erbaa turned into a wreck due to the earthquake in 1942, which was at its epicenter in Niksar district of Tokat province (N. Ambraseys \& Jackson, 2000; N. N. Ambraseys \& Jackson, 1998; Barka, 1996; Bikçe, 2016). Also, the Yeşilırmak and its biggest tributary, the Kelkit River, have damaged the Erbaa and Niksar districts many times in the past years (Altın, 2014; Koç \& Thieken, 2018; Öztunç, 2012). Although landslide is a hazard 
for all three settlements, Taşova has the highest rate of landslides (Bilgehan, 2004; Erkal \& Ateş, 2011). Consistent with this, students in Taşova perceive the risk of landslides greater than students in Erbaa and Niksar.

There is no doubt that the high level of students' perception and fear of earthquake risk is related to the fact that they live in an area with high earthquake risk. Moreover, in the recent past, two earthquakes with 4.9 and 4.00 magnitudes occurred in Erbaa on 9 October 2015. The results of the surveys conducted after the disaster events show that the fear and anxiety levels of the people who experienced disaster events are high (Cvetković, Öcal, \& Ivanov, 2019; K. Finnis et al., 2004; Kelly \& Ronan, 2018; McNeill \& Ronan, 2017; Ronan et al., 2008; Ronan \& Johnston, 1999; Shapira, Aharonson-Daniel, \& Bar-Dayan, 2018). Besides, in line with the findings of several studies focusing on the psychological effects of disasters (Dell'Osso et al., 2011; Fothergill, 1999; Gustafson, 1998), the research findings reveal that females feel more fear and anxiety about hazards than males.

According to the obtained results, it was not possible to state that students' knowledge of vital and total safety behavior related to hazards was good. There were very few students who correctly answered all items in the questionnaire dealing with protective behaviors, and there were also students who did not know any of these behaviors. Also, there were no students who correctly answered all questions in the disaster knowledge test prepared according to the course content in the current curricula, and overall, the DKT success level of the sample was moderate.

The earthquake and its protective safe behaviors were predominant in the curriculum of the primary and secondary schools in Turkey. The earthquake issues were included in the content of courses of Life Science up to the 3rd grade, Social Studies in the 4th grade, and Social Studies, and Turkish in the 5th grade. The reasons for the events such as fire, avalanche, flood, landslide, lightning, and the ways of protection from these hazards were included in the curriculum of the 7th grade Science and Technology Course. Science and Technology Course in the 8th grade included the effects of volcanoes and earthquakes on human life, earthquake hazard management, earthquake protective behaviors; meteorological disasters such as wind, tornado, hurricane, and the ways of protection from such hazards. However, although earthquake-related issues were predominant in teaching curricula, only $18 \%$ of the students could correctly mark the most vital behavior (to curl into a turtle shape and protect your head) for the earthquake, whereas one of the wrong behaviors (as soon as the shake starts, I get out immediately) was chosen by $93 \%$ of the students. "I immediately go out and look at the rising water", which is an expression of wrong behavior for the flood, was chosen by $91 \%$ of the students as their favorite protective behavior. "I leave the building in the shortest way", which is the vital option for the fires, was chosen by the majority of students, whereas the low averages of protective behaviors for avalanches, storm with high winds, and landslide may be related to less emphasis on these disasters in curricula. The protective behavior, disaster, risk, and hazard knowledge of almost all the students were limited to the content of lessons in schools only because no students had participated in a special hazard training program before. In this context, Finnis et al. (2010) reported that students who have participated in hazard education programs have a better knowledge of safety behaviors. Besides, significant differences in the results of the analysis based on school and settlement variables may be related to such factors as student and school profiles connected to socioeconomic level, and teachers' pedagogical competence in hazard education.

\section{Conclusion}

1. Topics about DRR were not sufficiently covered in the national curriculum, therefore, new mechanisms to increase awareness of DRR should be established.

2. At the primary school level, practical teaching/training rather than theoretical knowledge should be included. 
3. Courses on disaster risk management at universities are largely included in the curricula of associate and graduate programs on disaster management. These courses should be expanded to include university students studying in other programs, also, various symposiums and conferences should be organized on the topic.

4. DRR education modules should be prepared by considering different socio-cultural groups and these modules should be supported by pilot studies.

5. In-service DRR education should be organized for managers and public personnel.

6. Issues related to DRR need to be included more intensively in the formal education curriculum.

7. Inserting disaster risk reduction issues in distance learning systems, activating the "Earthquake Simulation Center" should be considered as tools that contribute to the increase of DRR awareness of the society.

8. Regular and continuous exercises should be conducted to increase the preparedness of the society for disasters.

9. Relations with local media should be established to provide information to people in the event of a disaster.

10. In particular, the Council of Higher Education, Ministry of National Education, local administrations, Ministry of Family and Social Policy, Presidency of Religious Affairs, and other relevant institutions and organizations should provide support for disaster risk reduction training programs.

Despite all these recommendations on DRR awareness and education, in the new formal education curricula that began to be implemented in the 2018-2019 academic year, the intermediary disciplined approach of the former curricula, valid during this study period, was abandoned, and Disasters and Safe Life intermediary discipline were also removed. The issues related to hazard, risk, and disaster were included only in Life Science, Social Studies, Science, and Technology courses in the new curriculum. For example, the "Safe Life" unit of the Life Science course from grade 1 to grade 3 focuses on hazards that students may encounter at school, at home, on playgrounds, in traffic, and on what to do in emergencies.

During the 12 years of compulsory education in Turkey, DRR education has been carried out with a non-holistic approach, as the issues related to the disaster have been distributed among different courses and never summed up. Unfortunately, in the new curriculum, the disaster-related content has been reduced, compared to the previous one. The disaster content of the new curriculum lacks topics such as contributing to the development of children's ability to cope with fear and anxiety about disasters, home-based practices. To achieve DRR, many things have to be done: child-parent cooperation and new teaching methods are to be developed. Also, relevant terminology has to be taught to teachers and students.

Teachers development and prospective teacher education is an important issue. It is considered a positive development in terms of DRR education of pre-service teachers that the "Disaster Education and a Safe Life" course has become a compulsory subject in some programs in at faculties of education in Turkey since 2018.

Some questions are still waiting to be answered, for example:

1. How will the content of courses dealing with DRR be structured?

2. Who will conduct these lessons or what should be the areas of expertise of the faculty members who will conduct these courses?

3. Will faculty members conducting these courses need to have a trainer's training certificate on DRR? 
The literature on disaster education reveals that there are many different approaches, tools, and target groups related to disaster education. Child-centered DRR, which recognizes children's particular needs and vulnerabilities, capacities, and rights, has been of significant interest in recent years (Shaw, Takeuchi, \& Shiwaku, 2011). "Child-centered DRR is a flexible rights-based approach combining child-focused (for children) and child-led (by children) activities with interventions geared towards bringing about change in community, local and national duty bearers. It applies strategies such as awareness-raising, capacity building, group formation, institutional development, research, and influencing and advocacy across a range of areas" (Plan, 2010, p. 5). Child-centered DRR applications with some examples in the world proved that children can communicate effectively on risk and risk reduction with their parents, siblings, and peers and through informal communication networks (ibid). Although Turkey's DRR plans also include children, however, Limoncu and Atmaca (2018) claim that there are no child-centered DRR plans that meet the above definition.

Undoubtedly, disaster education consists of process-based practices that have many links between school and community, between community and family, different disciplines, different stakeholders, nature and human, past and future, and so on (Shaw et al., 2011). This continuous disaster education process requires the participation of different groups of stakeholders from students and teachers to government, non-governmental organizations, media, and the private sector. Due to the lack of comparative studies testing the effectiveness of disaster education practices carried out through formal and informal education, currently, it is difficult to find evidence that there is an effective disaster education plan prepared as a result of the dialogue between different groups of stakeholders in Turkey. 


\section{References}

AFAD. (2014). Türkiye afet farkındalığı ve afetlere hazırlık araştırması. Retrieved from https://www.afad.gov.tr/upload/Node/3923/xfiles/turkiye-afet-farkindaligi-ve-afetlere-hazirlik-arastirmasi_-2014edited.pdf

AFAD. (2015). Turkey: National progress report on the implementation of the Hyogo Framework for Action (2013-2015). Retrieved from http://www.preventionweb.net/english/hyogo/progress/reports/

AFAD. (2016). Türkiye'nin afet yönetimindeki başarılı uygulamaları. Retrieved from https://www.afad.gov.tr/upload/Node/25327/xfiles/14aTurkiye nin Afet Yonetimindeki Basarili Uygulamalari Turkce.p $\underline{\text { df }}$

Akçil, Ö., Toğrol, A., Mercan, F. Ç., \& Tanırcan, G. (2014). Yeniden düzenlenmiş temel afet bilinci eğitim programının okul dışı bilim öğrenme ortamında etkililiğinin incelenmesi. Boğaziçi Üniversitesi Eğitim Dergisi, 31 (2), 99-126.

Akin, M.K., Topal, T., \& Kramer, S.L. (2013). A newly developed seismic microzonation model of Erbaa (Tokat, Turkey) located on seismically active eastern segment of the North Anatolian Fault Zone (NAFZ). Natural Hazards, 65(3), 1411-1442. https://doi.org/10.1007/s11069-012-0420-1

Altın, T. B. (2014). The Flood Risk of the Yeşilırmak Basin (upper course), Turkey. Procedia- Social and Behavioral Sciences, 120, 460-467. https://doi.org/10.1016/j.sbspro.2014.02.125

Ambraseys, N., \& Jackson, J. (2000). Seismicity of the Sea of Marmara. Geophysical Journal International, 14, F1-F6. https://doi.org/10.1046/j.1365-246x.2000.00137.x

Ambraseys, N. N., \& Jackson, J. A. (1998). Faulting associated with historical and recent earthquakes in the Eastern Mediterranean region. Geophysical Journal International, 133(2), 390-406. https://doi.org/10.1046/j.1365-246X.1998.00508.x

Aydin, F, \& Coskun, M. (2010). Observation of the students' "earthquake" perceptions by means of phenomenographic analysis (primary education 7th grade- Turkey). International Journal of the Physical Sciences, 5 (8), 1324-1330.

Barka, A. (1996). Slip distribution along the North Anatolian fault associated with the large earthquakes of the period 1939 to 1967. Bulletin of the Seismological Society of America, 86(5), 1238-1254.

Barka, A., Akyüz, H.S., Cohen, H.A., \& Watchorn, F. (2000). Tectonic evolution of the Niksar and Tasova-Erbaa pull-apart basins, North Anatolian Fault Zone: their significance for the motion of the Anatolian block. Tectonophysics, 322(3), 243-264. https://doi.org/https://doi.org/10.1016/S0040-1951(00)00099-8

Bikçe, M. (2016). A database for fatalities and damages due to the earthquakes in Turkey (1900-2014). Natural Hazards, 83(3), 1359-1418. https://doi.org/10.1007/s11069-016-2397-7

Bilgehan, P.R. (2004). Taşova (Amasya) dolayındaki heyelanların mühendislik jeolojisi incelemesi (Ankara Üniversitesi). Retrieved from http://onlinelibrary.wiley.com/doi/10.1002/cbdv.200490137/abstract

Bohnhoff, M., Martínez-Garzón, P., Bulut, F., Stierle, E., \& Ben-Zion, Y. (2016). Maximum earthquake magnitudes along different sections of the North Anatolian fault zone. Tectonophysics, 674, 147-165. https://doi.org/10.1016/j.tecto.2016.02.028 
Çelik, M. A., Bayram, H., \& Özüpekçe, S. (2018). An assessment on climatological, meteorological and hydrological disasters that occurred in Turkey in the last 30 years (1987-2017). International Journal of Geography and Geography Education, 38, 295310.

Cin, M. (2010). Sınıf öğretmeni adaylarının doğal afetler ile ilgili yanılgıları. Marmara Coğrafya Dergisi, (22), 70-81.

Cvetković, V. M., Öcal, A., \& Ivanov, A. (2019). Young adults' fear of disasters: A case study of residents from Turkey, Serbia and Macedonia. International Journal of Disaster Risk Reduction, 101095. https://doi.org/https://doi.org/10.1016/j.ijdrr.2019.101095

Danışman, I.G., \& Okay, D. (2017). Afetlerin çocuk ve ergenler üzerindeki etkileri ve müdahale yaklaşımları. Turkiye Klinikleri Psychology- Special Topics, 2 (3), 189-197.

Değirmençay, Ş.A. \& Cin, M. (2016). Türkiye'deki deprem eğitimi araştırmaları: Betimsel içerik analizi. YYü Eğitim Fakültesi Dergisi, 1, 301-313.

Dell'Osso, L., Carmassi, C., Massimetti, G., Daneluzzo, E., Di Tommaso, S., \& Rossi, A. (2011). Full and partial PTSD among young adult survivors 10 months after the L'Aquila 2009 earthquake: Gender differences. Journal of Affective Disorders, 131(1-3), 79-83. https://doi.org/10.1016/j.jad.2010.11.023

Dikmenli, Y. \& Gafa, İ. (2017). Farkı eğitim kademelerine göre afet kavramı. Mehmet Akif Ersoy Üniversitesi Eğitim Fakültesi Dergisi, (44), 21-36. https://doi.org/10.21764/maeuefd.335007

Dikmenli, Y. \& Yakar, H. (2019). Öğretmen adaylarının afet bilinci algı düzeylerinin incelenmesi. YYü Eğitim Fakültesi Dergisi, 16 (1), 0-2. https://doi.org/http://dx.doi.org/10.23891/efdyyu.2019.130

Dufty, N. (2011). Engagement or education? Australian Journal of Emergency Management, 26(3), 35-39.

Erdur-Baker, Ö., Kasapoğlu, K., \& Yılmaz, E. (2015). The objectives of disaster education from teachers' perspectives. Journal of Human Sciences, 12 (1), 975-990.

Erkal, T., \& Ateş, S.. (2011). Doğal tehlikelerin değerlendirilmesine bir örnek: Taşova. Coğrafi Bilimler Dergisi, 9(1), 61-77. Retrieved from http://dergipark.gov.tr/download/article-file/691194

Erkan, S. (2010). Deprem yaşayan ve yaşamayan okul öncesi çocukların davranışsal / duygusal sorunlarının karşılaştırmalı olarak incelenmesi. Pamukkale Üniversitesi Eğitim Fakültesi Dergisi, 28 (28), 55-66.

Fetihi, L. \& Gülay, H. (2011). The effect of earthquake awareness development program (EADP) on 6 years old children. International Online Journal of Educational Sciences, 3 (2), 663-678. Retrieved from http://ezproxy.lib.utexas.edu/login?url=http://search.ebscohost.com/login.aspx?direct=true\&db=eue\&AN=65156830\&s ite=ehost-live

Finnis, K.K., Johnston, D.M., Ronan, K.R., \& White, J.D. (2010). Hazard perceptions and preparedness of Taranaki youth. Disaster Prevention and Management: An International Journal Article Information, 19 (2), 175-184. https://doi.org/https://doi.org/10.1108/09653561011037986

Finnis, K., Standring, S., Johnston, D., \& Ronan, K. (2004). Children's understanding of natural hazards in Christchurch, New Zealand. Australian Journal of Emergency Management, 19 (2), 11-20.

Fothergill, A. (1999). Women's Roles in a Disaster. Applied Behavioral Science Review, 7(2), 125-143. 
Gulay, H. (2010). An earthquake education program with parent participation for preschool children. Educational Research and Review, 5(10), 624-630. Retrieved from https://onlinelibrary.wiley.com/doi/epdf/10.1111/risa.12545

Gustafson, P. E. (1998). Gender differences in risk perception: Theoretical and methodological perspectives. Risk Analysis, 18(6), 805-811. https://doi.org/10.1023/B:RIAN.0000005926.03250.c0

Johnson, V.A., Ronan, K.R., Johnston, D.M., \& Peace, R. (2016). Improving the impact and implementation of disaster education: Programs for children through theory-based evaluation. Risk Analysis, 36(11), 2120-2135. https://doi.org/10.1111/risa.12545

Kelly, B., \& Ronan, K. R. (2018). Preparedness for natural hazards: testing an expanded education- and engagement-enhanced social cognitive model. Natural Hazards, 91(1), 1-17. https://doi.org/10.1007/s11069-017-3093-y

Khan, H. \& Khan, A. (2008). Natural hazards and disaster management in Pakistan. Management \& Marketing - Craiova, 1, 43-50.

Kirikkaya, E.B., Çakin, O., Imali, B., \& Bozkurt, E. (2011). Earthquake training is gaining importance: The views of 4th and 5th-year students on earthquake. Procedia- Social and Behavioral Sciences, 15, 2305-2313. https://doi.org/10.1016/j.sbspro.2011.04.098

Kırıkkaya, E.B., Ünver, A.O., \& Çakın, O. (2011). Teachers views on the topic of disaster education at the field on elementary science and technology curriculum. Necatibey Eğitim Fakültesi Elektronik Fen ve Matematik Eğitimi Dergisi (EFMED), 5 (1), $24-42$.

Koç, G., \& Thieken, A. H. (2018). The relevance of flood hazards and impacts in Turkey: What can be learned from different disaster loss databases? Natural Hazards, 91(1), 375-408. https://doi.org/10.1007/s11069-017-3134-6

Lidstone, J., Stoltman, J. P., \& DeChano, Lisa. M. (2004) Natural disasters: raising public understanding about risk, occurrence, mitigation, and preparedness. In Stoltman, J. P., Lidstone, J., \& DeChano, L.M. (Eds.) International perspectives on natural disasters: occurrence, mitigation, and consequences. Vol. 21, pp. 1-10. Dordrecht/Boston/ London: Kluwer Academic Publishers.,

Limoncu, S., \& Atmaca, A. B. (2018). Çocuk Merkezli Afet Yönetimi. Megaron, 13(1), :132-143.

McNeill, I. M., \& Ronan, K. R. (2017). Children in disasters: the role of household preparedness. Natural Hazards, 89(3), 1239-1254. https://doi.org/10.1007/s11069-017-3019-8

MEB. (2018). Milli Eğitim Istatistikleri, Örgün Eğitim, 2017/2018. Retrieved from: http://sgb.meb.gov.tr/meb_iys_dosyalar/2018_09/06123056_meb_istatistikleri_orgun_egitim_2017_2018.pdf

Nielsen, S., \& Lidstone, J. (1998). Public education and disaster management: is there any guiding theory? Australian Journal of Emergency Management, 14-19.

Öcal, A. (2005). The evaluation of earthquake education in the elementary school social studies courses. Gazi Egitim Fakultesi Dergisi, 25 (1), 169-184.

Öcal, A. (2010). Hazard education in 4th to 7th grade social studies courses in Turkey. Social Studies Research and Practice, 5(1), $87-95$.

Öcal, A., Çakır, U., \& Özelmacı, Ş. (2016). İlkokul ve ortaokul ders programlarında afetten korunma ve güvenli yaşam. Alan Eğitimi Araştırmaları Dergisi (ALEG), 2 (2), 71-83. 
Öcal, A. \& Topkaya, Y. (2011). Earthquake preparedness in schools in seismic hazard regions in the South-East of Turkey. Disaster Prevention and Management: An International Journal, 20(3), 334-348. https://doi.org/https://doi.org/10.1108/09653561111141754

Oral, M., Yenel, A., Oral, E., Aydin, N., \& Tuncay, T. (2013). Earthquake experience and preparedness in Turkey. Disaster Prevention and Management, 24( 1), 21-37. https://doi.org/http://dx.doi.org/10.1108/MRR-09-2015-0216

Özgüven, B. (2006). ilköğretim öğrencilerine verilen temel afet bilinci eğitiminin bilgi düzeyine etkisi. (Doctoral dissertation), Dokuz Eylül Üniversitesi Sağlık Bilimleri Enstitüsü).

Özmen, B. \& İnce, Z. D. (2017). Okul tabanlı afet eğitimi. Dirençlilik Dergisi, 1(1), 21-29.

Öztunç, H. B. (2012). Tokat'ta büyük sel (1908). Trakya Üniversitesi Edebiyat Fakültesi Dergisi, 2(04), 179-203.

Pinar, A. (2017). What is secondary school students' awareness on disasters? A case study. Review of International Geographical Education Online, 7 (3), 315-331.

Plan, U. (2010). Child-Centred Disaster Risk Reduction: Building Resilience through Participation. In Finsgate: Plan United Kingdom. Retrieved from http://www.childreninachangingclimate.org/uploads/6/3/1/1/63116409/child centred drr-corepublication.pdf

Raju, E. \& da Costa, K. (2018). Governance in the Sendai: a way ahead? Disaster Prevention and Management: An International Journal, 27 (3), 278-291.

Ronan, K.R., Alisic, E., Towers, B., Johnson, V.A., \& Johnston, D.M. (2015). Disaster preparedness for children and families: a critical review. Current Psychiatry Reports, 17 (7), 1-9. https://doi.org/10.1007/s11920-015-0589-6

Ronan, K.R., Crellin, K., \& Johnston, D. (2010). Correlates of hazards education for youth: A replication study. Natural Hazards, 53 (3), 503-526. https://doi.org/10.1007/s11069-009-9444-6

Ronan, K. R., Crellin, K., Johnston, D. M., Finnis, K., Paton, D., \& Becker, J. (2008). Promoting child and family resilience to disasters: Effects, interventions, and prevention effectiveness. Children Youth and Environments, 18 (1), 332-353.

Ronan, K. R., \& Johnston, D. M. (1999). Behaviourally-based interventions for children following volcanic eruptions: An evaluation of effectiveness. Disaster Prevention and Management: An International Journal, 8(3), 169-176. https://doi.org/10.1108/09653569910275364

Ronan, K.R., \& Johnston, D.M. (2001a). Correlates of hazard education programs for youth. Risk Analysis, 21 (6), $1055-1063$. https://doi.org/10.1111/0272-4332.216174

Ronan, K. R., \& Johnston, D. M. (2001b). Correlates of Hazard Education Programs for Youth. Risk Analysis, 21(6), 1055-1064. https://doi.org/10.1111/0272-4332.216174

Ronan, K.R. \& Johnston, D.M. (2003). Hazards education for youth: A quasi-experimental investigation. Risk Analysis, 23 (5), 1009 1020. https://doi.org/10.1111/1539-6924.00377

Şengün, H. (2018). Afet yönetiminin kuramsal yapısı ve afet hukuku. In H. Şengün, S. G. M. Yıldız, \& B. Tercan (Eds.), Türkiye'nin Afet Yönetimi: Sosyal, Siyasal ve Yönetim Boyutuyla (pp. 133-160). Ankara: Palme Yayınevi.

Shapira, S., Aharonson-Daniel, L., \& Bar-Dayan, Y. (2018). Anticipated behavioral response patterns to an earthquake: The role of personal and household characteristics, risk perception, previous experience and preparedness. International Journal of Disaster Risk Reduction, 31(April), 1-8. https://doi.org/10.1016/j.jjdrr.2018.04.001 
Shaw, R. \& Kobayashi, M. (2001). Role of schools in creating earthquake-safer environment. Disaster Management and Educational Facilities. Retrieved from https://www.preventionweb.net/files/5342_SesiRoleSchoolsEQSafety.pdf

Shaw, R., Takeuchi, Y., \& Shiwaku, K. (2011). TSUNAGARU: the essence of disaster education. In R. Shaw, K. Shiwaku, \& Y. Takeuchi (Eds.), Disaster Education: Community, Environment and Disaster Risk Management (1st ed.), vol. 7, pp. 153-162). Bingley: Emerald Group Publishing Limited.

Shiwaku, K. \& Fernandez, G. (2011). Roles of school in disaster education. In R. Shaw, K. Shiwaku, \& Y. Takeuchi (Eds.). Disaster Education: Community, Environment and Disaster Risk Management (1st ed., pp. 45-75). vol. 7. Bingley, UK: Emerald Group Publishing Limited.

Smyth, J. C. (1996). A national strategy for environmental education: an approach to a sustainable future? Environmentalist, 16 (1), 27-35.

Sözcü, U. \& Aydınözü, D. (2019). Öğretmen adaylarının doğal afet okuryazarlık düzeylerinin çeşitli değişkenlere göre incelenmesi. Lnternational Journal of Geography and Geography Education, 40, 79-91.

TaşCI, F.Ö., \& Ünver, A.O. (2017). Broad-based participatory inquiry into the definition and scope of disaster. Journal of Education in Science, Environment and Health, 3 (2), 165-165. https://doi.org/10.21891/jeseh.326743

TMMOB Makina Mühendisleri Odası. (2012). Türkiye'de Deprem Gerçeği ve TMMOB Makina Mühendisleri Odası'nın Önerileri Oda Raporu. Retrieved from http://www1.mmo.org.tr/resimler/dosya_ekler/ee9b8f616afde72_ek.pdf

UNICEF \& UNISDR. (2011). Children and disasters: Building resilience through education. Retrieved from https://www.unisdr.org/files/24583_childrenanddisastersbuildingresilie.pdf

UNISDR, (2007). 2006-2007 World Disaster Reduction Campaign: Disaster risk reduction begins at school, Retrieved from https://www.unisdr.org/files/2105_VL108003.pdf

UNISDR. (2015). 2014-15 Biennium Work Programme Final Report. Retrieved from https://www.unisdr.org/files/48588_unisdrannualreport2015evs.pdf

United Nations. (2015). Sendai framework for disaster risk reduction 2015-2030. Retrieved from https://www.preventionweb.net/files/43291_sendaiframeworkfordrren.pdf

United Nations General Assembly. (2016). Report of the open-ended intergovernmental expert working group on indicators and terminology relating to disaster risk reduction. Retrieved from https://mpra.ub.unimuenchen.de/11052/1/MPRA_paper_11052.pdf

United Natıons Office For Disaster Risk Reduction (UNDRR). (2017). Terminology. Retrieved from https://www.undrr.org/terminology

Yılmaz, E. (2014). School-based disaster education through curricular and extra-curricular activities: a comparative case study (Middle East Technical University). Retrieved from http://etd.lib.metu.edu.tr/upload/12617145/index.pd 